\title{
КОНЦЕПЦИЯ ЭВОЛЮЦИОННОГО ПЕРЕХОДА К ЧЕЛОВЕКООРИЕНТИРОВАННОМУ ГЛОБАЛЬНОМУ УПРАВЛЕНИЮ
}

\author{
Бурьянов С. А., Бурьянов М. С.
}

Статья посвящена исследованию перспектив преодоления глобальных вызовов и эволючионного системного перехода к глобальной человекоориентированной цифровой системе управления глобальными процессами в целях устойчивого развития через развитие глобального сотрудничества в сфере права и юридического образования. Рассмотрень современные глобальные прочессы и вызовы 4.0 и определены основные направления формирования концепции человекоориентированного глобального управления в целях устойчивого развития. Авторы делают вывод о необходимости создания глобальной системь международного сотрудничества в сфере права и юридического образования. Права человека определены в качестве основы современного правопонимания, а также формирующихся глобальных права и управления. Обосновывается необходимость правового закрепления и реализачии нового поколения глобальных цицровых прав человека.

Ключевые слова: глобальные процессы, глобальные вызовы, ичифровая глобализация, устойчивое развитие, глобальное управление, глобальное право, глобальное юридчческое образование, права человека.

The article is devoted to the study of the prospects for overcoming global challenges and the evolutionary systemic transition to a global human-oriented digital system for managing global processes for sustainable development through the development of global cooperation in the field of law and legal education. The modern global processes and 4.0 challenges are considered. The main directions of formation of the concept of human-oriented global governance for sustainable development are identified. The authors conclude that it is necessary to create a global system of international cooperation in the field of law and legal education. Human rights are identified as the basis of modern legal thinking, as well as emerging global law and governance. The necessity of legal consolidation and implementation of a new generation of global digital human rights is substantiated.

Keywords: global processes, global challenges, digital globalization, sustainable development, global governance, global law, global legal education, human rights.

* Бурьянов Сергей Анатольевич - к. ю. н., доцент Московского городского педагогического университета. E-mail: burianov-msk@yandex.ru.

Бурьянов Максим Сергеевич - юрист, эксперт Global Shapers Community Moscow, координатор Global Law Forum, эксперт молодежной группы стран СНГ МСЭ OOH (ITU UN). E-mail: maksim.burianov@yandex.ru. 
На современном этапе развитие планетарных общественных, а также связанных с ними природных, техногенных и космических взаимодействий существенно ускорилось. Но при этом обусловленная неравномерностью развития разбалансированность в развитии общественно-техноприродных взаимодействий привела не только к обострению старых угроз международной безопасности, но и к появлению новых глобальных вызовов, многие из которых связаны с новыми цифровыми технологиями [Бурьянов М. С., Бурьянов С. А. 2020]. В условиях динамичного изменения современных общественно-техноприродных (и космических) взаимодействий, с одной стороны, направленных на рост технологического прогресса и формирование единой глобальной системы, а с другой, - несущих нестабильность международных отношений и новые глобальные угрозы безопасности [Farkhutdinov 2020], представляется актуальным исследование перспектив международного сотрудничества для формирования глобального управления в целях устойчивого развития.

Устойчивое развитие считается позитивной альтернативой глобальным вызовам. Этот термин нашел отражение в трудах ученых и деятельности международных организаций (Римского клуба, Международного союза охраны природы и природных ресурсов, Международной комиссии по окружающей среде и развитию и др.). Под устойчивым развитием нами понимается «управляемый интегрированный сбалансированный и урегулированный процесс реализации жизненно важных интересов человечества (включая будущие поколения), в гармонии с природой» [Бурьянов 2019].

В начале 2021 г. генеральный секретарь Организации Объединенных Наций А. Гуттериш в ходе своего выступления на заседании Генеральной Ассамблеи ООН обозначил основные вызовы и приоритеты работы по их преодолению: победа над глобальной вирусной пандемией; восстановление экономики с акцентом на возобновляемых источниках энергии; «установление мира с природой» на основе сдерживания изменений климата, сокращения глобальных выбросов и сохранения биоразнообразия; борьба с «пандемией нищеты и неравенства» с опорой на образование и цифровые технологии; противодействие нарушениям прав человека; борьба с гендерным неравенством; «преодоление геополитических расколов и поиск точек соприкосновения», включая «глобальное прекращение огня» и необходимость существенного повышения эффективности миротворческих операций; «обращение вспять процесса эрозии режима ядерного разоружения и нераспространения〉 в контексте взаимоотношений ядерных держав; необходимость защиты от угроз, связанных с внедрением новых цифровых технологий, включая необходимость запрета боевых автономных систем, а также преодоление цифрового неравенства; «перезагрузки в XXI веке». Также А. Гуттериш подчеркнул необходимость эффективного глобального управления.

В указанном контексте также следует согласиться с А. Н. Чумаковым, который говорит об актуальности «глобальной цивилизационной революции, которая стала бы мощным импульсом формирования глобального гражданского общества, а в международных отношениях запустила бы процесс перехода от права силы к силе права» в качестве условия построения нового устойчивого безопасного мирового порядка. Исследователь также отмечает необходимость выработки механизмов реализации проектов глобального переустройства мира (мирного сосуществования, устойчивого развития, ноосферы и др.) [Чумаков 2018]. 
Э. Г. Кочетов предложил «парадигму мирового преображения как несущую конструкцию нового мыслительного поля - гуманитарную космологию - антропокосмологическую модель бытия» [Кочетов 2017]. Данный автор констатирует необходимость фундаментального пересмотра сложившейся системы международных отношений на основе парадигмальной связки «геоэкономика - глобалистика - гуманитарная космология», отметив приоритет человека и его свободы [Кочетов 2019].

Также в качестве отправной точки данного исследования можно указать ряд статей журнала «Век глобализации», посвященных концепции глобального управления [Бурьянов 2019; Вебер 2009; Гринин 2016; Дробот 2011; Ильин, Каверин 2014; Ильин, Леонова 2015; Урсул 2014; Чумаков 2010; 2012 и др.].

В целом «среди наиболее известных подходов к формированию концепции управления глобальными процессами - мировое государство (правительство), глобальная управленческая система на основе $\mathrm{OOH}$ и межправительственных организаций, а также ее варианты с участием транснациональных корпораций и неправительственных организаций» [Бурьянов 2019]. При этом концепция сетевого децентрализованного управления с усилением роли негосударственных акторов с условным названием «управление без правительства» («governance without government») менее известна [Rosenau 1992; Slaughter 2004].

Обобщив многообразие подходов, «можно определить глобальное управление (Global Governance) как планетарную систему принципов (основополагающих начал), норм (правил поведения) и институтов, приемов и методов, направленных на преодоление глобальных вызовов и достижение устойчивого человекоориентированного развития цивилизации» [Бурьянов 2019].

Современные исследователи рассматривают глобализацию как совокупность в основном объективных макромасштабных процессов, направленных на формирование единой интегрированной планетарной системы [Чумаков 2011; 2018]. Около двадцати лет назад начался новый этап глобализации, сулящий небывалые возможности, вытекающие из внедрения новых технологий 4.0 (большие данные, искусственный интеллект, роботизация, Интернет вещей, трехмерная печать, нанотехнологии, биотехнологии, материаловедение, накопление и хранение энергии, квантовые вычисления) [Schwab 2018]. Уточним, что «концепция "Индустрия 4.0" предполагает эволюционный переход от простой цифровизации (третья промышленная революция) к гибридным, конвергентным технологиям (четвертая промышленная революция), характеризующимся трансформацией в цифровое производство» [Лепеш 2020].

Глобальные процессы 4.0 - качественно новый этап развития общества - совокупность процессов, направленных на формирование единой общественной системы, а также техносферы, сил природы и космоса, основанных на инновационных цифровых технологиях. Глобальные вызовы 4.0 - новые глобальные негативные последствия планетарного масштаба в сфере общественно-техноприродных (и космических) взаимодействий, связанные с внедрением инновационных цифровых технологий. По крайней мере некоторые из них чреваты прекращением существования человеческой цивилизации и требуют соответствующих совместных объединенных усилий человечества.

Новые глобальные вызовы 4.0 устойчивому развитию в последние годы проявляют себя все сильнее. Появляется все больше фактов, позволяющих утвер- 
ждать, что развитие и внедрение новых технологий может привести к существенным неправовым ограничениям прав человека. В частности, весьма неоднозначные и фактически не урегулированные правом системы тотальной слежки внедряются в ряде государств.

Разработка боевых роботизированных систем уже не является фантастикой. Современные исследователи указывают на усиление роли цифровых технологий в качестве составляющих военно-политического потенциала государств, попутно отмечая возрастание соответствующих вызовов [Ромашкина и др. 2020]. О проблемах цифровой милитаризации, включая ее влияние на ядерное оружие, пишет ряд зарубежных авторов [Harris 2014; Futter 2018]. Крайне серьезные цифровые угрозы современные исследователи видят в сверхсильном искусственном интеллекте, который может быть создан в будущем [Bostrom 2014].

В докладе ООН UNDESA World Social Report 2020 отмечается, что глобальные технологии 4.0 несут не только преимущества и улучшение жизни людей, но и могут усилить социальное неравенство и обострить глобальные вызовы [UNDESA... 2020]. Различные аспекты кибербезопасности, начиная с кибератак и заканчивая фрагментацией киберпространства, способны существенно обострить геополитическую напряженность [Wild...].

Реализация весьма спорных концепций «цифрового государственного суверенитета», «цифровых национальных интересов» и «цифровой национальной безопасности» (за которыми стоят узкие интересы элит) чреваты усилением и без того чрезмерного неравенства и обострением проблем глобальной безопасности.

В указанном контексте для преодоления современных глобальных вызовов необходимо постепенное эволюционное формирование новой системы управления глобальными процессами 4.0. Представляется, что опираться необходимо на концепцию «управления без правительства», предполагающую уменьшение централизации, отказ от применения силы в международных отношениях, верховенство права, приоритет прав человека и социальной справедливости, мировоззренческий нейтралитет государств, толерантность и противодействие нетерпимости [Бурьянов 2002; 2009]. В современных реалиях только такая человекоориентированная система глобального управления будет способствовать достижению устойчивого развития цивилизации и отдельных государств, включая Россию. В свою очередь, для этого необходимо опережающее формирование глобального права и интегрированного с наукой юридического образования.

Идея глобального права нашла отражение в трудах современных исследователей [Коршунов 2010; Курчеев и др. 2008; Урсул 2012; Фархутдинов 2004; Чумаков 2012; Шумилов 2003]. Тенденциям формирования глобальных юридических науки и образования также посвящен ряд современных исследований [Бурьянов 2017; Лиферов 1997; Марченко 2009; Урсул 2019; Чумаков 2019].

Развитие глобального права (как науки, нормативной системы и совокупности учебных дисциплин) необходимо в качестве первичной основы адекватного глобального управления. В качестве исходного материала следует рассматривать международное право, а также внутригосударственные правовые системы. При этом эффективное реформирование ООН и других международных организаций следует осуществлять не раньше реформирования принципов и норм международного права. В первую очередь реформы принципов и норм международного 
права должны быть направлены на повышение их эффективности для осуществления возможностей и всестороннего развития каждого индивида.

Однако для того, чтобы инновационная нормативная система была создана в планетарном масштабе, необходимы новые юридические кадры. Также они необходимы для эффективного правоприменения. Именно для этого крайне важно сформировать современное глобальное юридическое образование.

Соответственно, переход к децентрализованной системе управления в планетарном масштабе должен быть эволюционным, что требует создания инновационных знаний, а затем и нормативных регуляторов, на основе которых можно будет осуществить реформу управленческих институтов. Необходимо учитывать роль городов глобального значения в качестве этапа формирования глобального управления.

Системность, непрерывность и эволюционность перехода - важные условия эффективности и реалистичности формирования системы управления глобальными процессами в целях преодоления глобальных вызовов и достижения устойчивого развития цивилизации. Плавный эволюционный переход от иерархической к полииерархической и, наконец, к неиерархической системе глобального управления требует системной работы на всех основных уровнях.

Прежде всего на системообразующем научно-образовательном уровне в качестве организационной основы для разработки научно обоснованных рекомендаций и создания системы подготовки кадров необходимо формирование Международного центра (сети) глобального права и юридического образования. На этой базе будет создана глобальная академическая дискуссионная среда (сеть), в том числе мировая сеть кафедр, научных центров, ассоциаций глобального права и юридического образования. В идеале она должна стать глобальной децентрализованной сетевой научно-образовательной структурой.

На производном от научно-образовательного нормативно-правовом уровне можно предложить следующие приоритеты деятельности. Прежде всего для кардинального реформирования принципов и норм международного права во взаимодействии с внутригосударственными правовыми системами в качестве основы глобальной нормативной системы (права) необходимо в рамках работы Международного центра (сети) глобального права и юридического образования наладить взаимодействие и предложить научно обоснованные рекомендации $\mathrm{OOH}$, ее специализированным учреждениям и экспертным структурам, связанным с $\mathrm{OOH}$, а также иным международным организациям. Далее на основе международного сотрудничества с использованием распределенных платформ (реестров) необходимо разработать глобальную сетевую техно-правовую систему.

Далее, на правоприменительном уровне предлагается инициировать и последовательно реализовать программы: 1) кардинального реформирования $\mathrm{OOH}$ и усиления взаимодействия с региональными международными межправительственными и неправительственными организациями; 2) усиления взаимодействия и интеграции ООН с государствами; 3) формирования адекватной глобальной цифровой системы управления на базе глобальной техно-правовой платформы. Эффективность реализации концепции может и должна быть повышена с опорой на институты гражданского общества, СМИ и массовые коммуникации.

Суть данной концепции заключается в постепенном плавном эволюционном переходе к неиерархической децентрализованной человекоориентированной си- 
стеме управления глобальными процессами через развитие глобальных права и юридического образования, с перспективой реформирования на этой основе международных институтов.

Базовые ценности данной концепции перехода к человекоориентированному глобальному управлению (свобода, самосознание, самореализация, самоопределение, развитие, равноправие, справедливость, взаимоуважение, солидарность, гармония, здоровье, семья, образование и др.) призваны воплотиться в правах человека, которые выступают в качестве основы правопонимания.

Разработка и реализация концепции нового поколения глобальных цифровых прав человека призвана обновить юридические обязательства государств в контексте новой эпохи цифровой глобализации 4.0 [Бурьянов 2019; 2020; Buryanov 2020].

Особо отметим необходимость определения основных направлений реформирования правовых механизмов реализации свободы мировоззренческого выбора на основе авторской инновационной парадигмы [Бурьянов 2002; Бурьянов 2009] и принципа мировоззренческого нейтралитета государств и других субъектов международного права [Buryanov 2018].

С правами человека неразрывно взаимосвязаны правовые основы толерантности «как взаимоуважения вне зависимости от различий, а также противодействие ксенофобии, нетерпимости и дискриминации» [Бурьянов 2009; Buryanov 2018]. «С правовой точки зрения толерантность - это взаимоуважение к правам индивидов и сообществ вне зависимости от различий на основе равноправия при условии правомерности внешне выраженного поведения» [Buryanov 2018]. Ксенофобия, в том числе ее составляющие в виде негативных стереотипов и социальных установок, - это антипод толерантности. Создавая условия для неравноправия, она препятствует реализации прав человека, что чревато воспроизводством барьеров, препятствующих глобальному сотрудничеству, и конфликтами.

На практическую реализацию прав человека, свободы мировоззренческого выбора, толерантности и базовых ценностей, а также на преодоление произвола и злоупотреблений властью направлена еще одна ключевая составляющая концепции, посвященная правовому закреплению и воплощению принципа верховенства права во главе с принципом правовой определенности.

Формирование человекоориентированных глобальных цифровых нормативной системы (права) и системы глобального управления позволит принимать управленческие решения в режиме реального времени без проволочек, что крайне важно в условиях перманентных и беспрецедентных усложнения, ускорения, расширения общественно-техноприродных взаимодействий. Таким образом, достижение эффективности реализации концепции управления глобальными процессами для преодоления глобальных вызовов и перехода к устойчивому развитию опирается на упомянутые выше системность и цифровые технологии.

В частности, базовые характеристики blockchain - планетарный масштаб, публичность, открытость, прозрачность, непрерывность, быстродействие, децентрализация, безопасность, конфиденциальность, защищенность данных, независимость, стабильность, наличие памяти, равноправие участников, консенсуальность, возможность работы в режиме реального времени, отсутствие посредников, низкая комиссия, широкий диапазон применения - способны решить про- 
блемы институционализации доверия, минимизируют операционные издержки и в значительной мере соответствуют задачам формирования адекватной системы глобального управления. Также они способны решить проблемы демонополизации власти и собственности, перехода к прямой демократии, самоисполнения правовых норм, реализации прав человека, равномерного распределения благ и социальной справедливости, преодоления коррупции и повышения эффективности управления.

Практическая реализация концепции может быть достигнута путем последовательного осуществления программ, начиная с научно-образовательного (прежде всего в сфере юридических науки и образования) уровня. Затем будут реализованы программы правотворческого уровня и правоприменительного (в том числе международного сотрудничества и государственного управления). Реализация программ вспомогательных уровней гражданского общества, а также СМИ и массовых коммуникаций, может осуществляться одновременно с упомянутыми выше уровнями и призвана повысить эффективность воплощения концепции.

Ключевые положения и ценности концепции (права человека, свобода мировоззренческого выбора, толерантность, мировоззренческий нейтралитет, верховенство права) направлены на предотвращение конфликтов и войн, достижение защищенности от угроз. Центральное ноу-хау концепции - реализация мировоззренческого нейтралитета государств и других субъектов международного права и новая парадигма свободы мировоззренческого выбора как «противоядие» от этноконфессиональных барьеров, конфликтов и насилия на их почве. Реализация концепции направлена на достижение безопасности не только наций, этнических и религиозных групп, но каждого человека, вне зависимости от принадлежности к каким-либо группам.

Крайне важна теоретическая разработка и практическая реализация адекватной современным реалиям не силовой (не полярной) концепции международных отношений. В условиях обострения глобальных рисков одно-, двух-, и даже многополярная модели не способны решить проблемы мира и безопасности на планете, так как допускают применение силы [Бурьянов М. С., Бурьянов С. А. 2020].

Адаптивность изначально заложена в основу концепции, которая предполагает не модель управления, а концепцию эволюционного системного перехода к глобальной человекоориентированной цифровой системе управления глобальными процессами для преодоления глобальных рисков и достижения устойчивого развития цивилизации. Такой подход предполагает непрерывный пересмотр и совершенствование ее структуры и компонентов. При этом в идеале развитие программ системообразующего научно-образовательного уровня (прежде всего юридических науки и образования) должно быть опережающим и непрерывным. С учетом перманентного увеличения скорости, сложности, масштаба общественно-техноприродных взаимодействий такой подход представляется наиболее эффективным. Скорее всего, любая жесткая модель глобального управления быстро устареет и утратит эффективность.

Ответственность, прозрачность и противоядие от злоупотреблений при формировании новой системы управления общественными процессами крайне важны. Они заключаются в ограничении и децентрализации власти, а также в реализации прав человека [Бурьянов 2020]. Переход от основанных на полюсах силы 
международных отношений к их несиловой концепции направлен на ограничение злоупотреблений власти. Мировоззренческий нейтралитет государств также направлен на ограничение власти в эксплуатации религиозного авторитетадоверия высокого уровня. Он способствует десакрализации властей предержащих путем пресечения коррупции в отношениях государства и религиозных объединений [Бурьянов 2002; 2009; Buryanov 2018].

Таким образом, перспективы развития глобального управления связаны с постепенным переходом от иерархической к полииерархической, а затем и неиерархической системе глобального человекоориентированного сетевого цифрового управления. Реализация базовых ценностей на основе цифровых, в том числе blockchain, технологий призвана обеспечить ответственность и прозрачность, а также столь необходимую в современных реалиях оперативность, безопасность, децентрализацию и т. д.

Ответственность, прозрачность и легитимность также могут быть обеспечены за счет реализации концепции постепенного плавного эволюционного перехода к человекоориентированной неиерархической несиловой децентрализованной цифровой системе управления глобальными процессами через развитие глобальной нормативной системы и юридического образования. Далее будет возможно реформирование на этой основе международных институтов, прежде всего ООН, и их взаимодействия (интеграции) с межправительственными и неправительственными международными организациями и государствами. Таким образом, легитимность формирующейся системы управления глобальными процессами может быть унаследована от ООН.

В современных условиях устойчивое развитие является условием позитивного развития глобальных процессов, выживания человечества и процветания отдельных государств. Формирование на планетарном уровне доступной для каждого интегрированной научно-образовательной системы, реализация глобальных программ доступности базовых услуг (включая образование, здравоохранение и социальное обеспечение) на базе современных цифровых технологий могло бы стать весомым вкладом в достижение социальной справедливости в целях устойчивого развития.

В целом отметим, что нерешенность глобальных вызовов становится все более реальной угрозой существованию человеческой цивилизации, а уже существующие и формирующиеся новые глобальные вызовы являются следствием дисбаланса в развитии глобальных процессов. В частности, это проявляет себя в отсутствии эффективного и доступного глобального здравоохранения, но при наличии набирающей обороты глобальной гонки вооружений. Соответственно, эффективные решения глобальных вызовов следует искать в русле установления баланса и формирования условий перехода к устойчивому управляемому росту, а не к его ограничению, как это предлагают некоторые эксперты. Для этого необходимо усиление роли ООН в формировании правовых и организационных основ современной системы глобального управления. С целью поиска и создания нового механизма глобального управления М. С. Бурьянов как эксперт молодежной группы стран СНГ МСЭ ОOH (ITU UN) реализует проект Global Law Forum - Ceтевое сообщество, ориентированное на достижение устойчивого развития (http:// maxlaw.tilda.ws/). 
В указанном контексте для России крайне важно осуществить реформирование системы образования с учетом современных глобальных процессов. От этого в очень значительной мере будут зависеть место страны в мировом сообществе и ее вклад в преодоление глобальных вызовов, достижение устойчивого развития. В указанном контексте представляется необходимым ввести во всех университетах учебную дисциплину «Глобалистика», а в юридических вузах, факультетах и институтах - учебную дисциплину «Правовая глобалистика».

Выводы:

1. Современные глобальные процессы направлены на формирование интегрированной планетарной общественно-техноприродной (и космической) системы и достижение состояния интеграции, взаимопроникновения, взаимозависимости и открытости.

2. Неравномерность развития формирующейся планетарной общественнотехноприродной системы в виде отставания политической, правовой и образовательной подсистем предопределяет их разбалансированность и глобальные негативные последствия (вызовы, а также проблемы, угрозы, риски, кризисы, катастрофы и др.). При этом нерешенность как минимум некоторых из них угрожает существованию цивилизации.

3. Современные глобальные процессы 4.0 несут не только небывалые возможности улучшения жизни людей, но и новые глобальные вызовы - цифровые милитаризацию, системы тотальной слежки, неравенство, угрозы кибербезопасности, а также сверхсильный искусственный интеллект.

4. Устойчивое управляемое развитие (управляемый рост) является позитивной альтернативой нерешенности глобальных вызовов и требует преодоления этноконфессиональных и иных барьеров, укрепления международного сотрудничества и интеграции на основе осуществления принципов толерантности и мировоззренческого нейтралитета.

5. Стратегическим направлением преодоления глобальных вызовов и достижения устойчивого управляемого развития является человекоориентированное децентрализванное неиерархическое несиловое цифровое глобальное управление общественно-техноприродными (и космическими) взаимодействиями.

6. Формирование и постепенный эволюционный переход к человекоориентированному глобальному управлению требует опережающего приоритетного развития человекоориентированного глобального права как науки, системы принципов и норм, совокупности учебных дисциплин (юридического образования). Глобальная интегрированная правовая научно-образовательная система призвана сформировать концептуальную, нормативную и кадровую основу для эффективного урегулирования общественно-техноприродных (и космических) взаимодействий, достижения баланса глобальных подсистем и в итоге - преодоления глобальных вызовов и перехода к устойчивому развитию.

7. Основой формирующегося глобального права является требующее реформирования международное право во взаимодействии с внутригосударственными правовыми системами, а также с иными регулятивными системами.

8. Важными принципами формирования человекоориентированных глобальных права и управления являются: приоритет прав человека, социальная справедливость, толерантность и противодействие нетерпимости, мировоззренческий 
нейтралитет субъектов международного права, верховенство права, правовая определенность, системность, универсальность, адаптивность, ответственность, прозрачность и др.

9. Для формирования и постепенного эволюционного перехода к человекоориентированному глобальному управлению необходима системная работа на всех основных и вспомогательных уровнях: научно-образовательном, нормативном, правоприменительном, а также гражданского общества, СМИ и массовых коммуникаций.

10. Флагманским проектом по реализации концепции перехода к человекоориентированному глобальному управлению должно стать формирование глобальной системы сотрудничества в сфере права и юридического образования.

11. Права человека как принадлежащие каждому от рождения возможности для развития, в том числе через пользование социальными благами (включая образование, здравоохранение, социальные услуги и др.), закрепленные в системе форм международного и внутригосударственного права, - основа современного понимания права, а также формирующихся глобальных права и управления.

12. В условиях глобальных цифровизации и вызовов 4.0 одним из ключевых условий формирования и постепенного эволюционного перехода к человекоориентированному глобальному управлению является необходимость правового закрепления и реализации нового поколения глобальных цифровых прав человека.

\section{Литература}

Бурьянов С. А. Проблемы совершенствования нормативно-правовой базы реализации права на свободу совести в контексте глобализации // Государство и право. 2002. № 10. C. 26-31.

Бурьянов С. А. Свобода совести как глобальная ценность. На пути к политическому единству и решению глобальных проблем // Век глобализации. 2009. № 1. C. $136-151$.

Бурьянов С. А. Некоторые подходы к определению понятия глобализации образования в контексте проблемы формирования системы управления глобальными процессами в интересах устойчивого развития // Ценности и смыслы. 2017. № 6(52). C. $36-49$.

Бурьянов С. А. О необходимости глобального права в контексте проблемы целенаправленного формирования глобальной системы управления в целях устойчивого развития // Век глобализации. 2019. № 4. C. 129-142. DOI: 10.30884/vglob/2019.04.12.

Бурьянов М. С. Глобальные цифровые права человека в контексте рисков цифровизации // Век глобализации. 2020. № 3. С. 21-37. DOI: 10.30884/vglob/2020.03.05.

Бурьянов М. С., Бурьянов С. А. Новые угрозы глобальной безопасности и перспективы развития международного права // Евразийский юридический журнал. 2020. № 11(150). С. 35-40.

Бурьянов С. А., Кривенький А. И. О состоянии и перспективах формирования глобального образования, включая юридическое // Государство и право. 2019. № 8. C. 95-100.

Вебер А. Б. Современный мир и проблема глобального управления // Век глобализации. 2009. № 1. С. 3-15. 
Гринин Л. Е. Возможности и перспективы формирования нового мирового порядка // Век глобализации. 2016. № 1-2. С. 3-18.

Гринин Л. Е., Гринин А. Л. Грядущая технологическая революция и глобальные риски // Век глобализации. 2016. № 4. С. 40-58.

Дробот Г. А. Проблема глобального управления в контексте теории международных отношений // Век глобализации. 2011. № 2. С. 41-52.

Ильин И. В., Каверин М. А. Вопросы преобразования международных организаций в институты глобального управления // Век глобализации. 2014. № 2. С. 32-37.

Ильин И. В., Леонова О. Г. Тенденции развития глобализационных политических процессов // Век глобализации. 2015. № 1. С. 21-35.

Коршунов А. Н. Идея глобального права : философско-методологические аспекты : дис. ... канд. филос. наук. Ростов-на-Дону, 2010.

Кочетов Э. Г. Парадигма Мирового Преображения как модель будущего (ее суть в максимально сжатом виде) // Век глобализации. 2017. № 3(23). С. 51-60.

Кочетов Э. Г. Контур будущего России: стратегия «Геоэкономический ход» // Век глобализации. 2019. № 2(30). С. 136-148.

Курчеев В. С., Болотникова О. В., Герасимов Ю. Е. Теоретические основы систематизации права в условиях глобализации. Новосибирск : Новосибирский государственный аграрный университет, 2008.

Лепеш Г. В. Совершенствование форм взаимодействия между предприятиями в контексте цифровой трансформации // Технико-технологические проблемы сервиса. 2020. № 2(52). C. 3-10.

Лиферов А. П. Основные тенденции интеграционных процессов в мировом образовании : дис. ... докт. пед. наук. Рязань, 1997.

Марченко М. Н. Государство и право в условиях глобализации. М. : Проспект, 2009.

Ромашкина Н. П., Марков А. С., Стефанович Д. В. Международная безопасность, стратегическая стабильность и информационные технологии. М. : ИМЭМО РАН, 2020.

Урсул А. Д. Глобализация права и глобальное право : концептуально-методологические проблемы // Право и политика. 2012. № 8. С. 1284-1297.

Урсул А. Д. Глобальное управление : эволюционные перспективы // Век глобализации. 2014. № 1. С. 16-28.

Урсул А. Д. Становление образования глобального мира // Век глобализации. 2019. № 2. С. 49-60.

Фархутдинов И. 3. Международное или глобальное право // Юрист-международник. 2004. № 4. С. 15-23.

Чумаков А. Н. Глобальный мир: проблема управления // Век глобализации. 2010. № 1. C. 3-15.

Чумаков А. Н. Культура и вызовы глобализации: новые подходы // Век глобализации. 2011. № 2(8). С. 174-180.

Чумаков А. Н. Проблема управления как повод для дискуссии // Век глобализации. 2012. № 2. С. 35-42. 
Чумаков А. Н. Основные тренды мирового развития : реалии и перспективы // Век глобализации. 2018. № 4(28). С. 3-15. DOI: https://doi.org/10.30884/vglob/2018.04.01.

Чумаков А. Н. Глобальный мир : столкновение интересов: монография. М., 2019.

Шумилов В. М. Концепция Глобальной правовой системы // Юрист-международник. 2003. № 3. С. 46-52.

Bostrom N. Superintelligence. Paths, Dangers, Strategies. Oxford : Oxford University Press, 2014.

Buryanov M. Here's why we need a Declaration of Global Digital Human Rights. World Economic Forum. 2020 [Электронный ресурc]. URL: https://www.weforum.org/ agenda/2020/08/here-s-why-we-need-a-declaration-of-global-digital-human-rights/ (дата обращения: 21.05.2021).

Buryanov S. A. State Worldview Neutrality in the Context of Deteriorating Imbalances in Globalization. Amsterdam : International Humanist and Ethical Union, 2018.

Farkhutdinov I. The Mysterious and Obvious in American Diplomacy: From Monroe to Trump. Newcastle upon Tyne : Cambridge Scholars Publishing, 2020.

Futter A. Hacking the Bomb: Cyber Threats and Nuclear Weapons. Georgetown : Georgetown University Press, 2018.

Harris S. War : The Rise of the Military-Internet Complex. Boston : Houghton Mifflin Harcourt, 2014.

Rosenau J. N., Czempiel E.-O. Governance Without Government : Order and Change in World Politics. Cambridge : Cambridge University Press, 1992.

Schwab K. Shaping the Fourth Industrial Revolution. Cologny; Geneva : Portfolio Penguin, 2018.

Slaughter A. M. A New World Order. Princeton; Oxford : Princeton University Press, 2004.

UNDESA World Social Report 2020 [Электронный ресурс] : URL: https:/www.un. org/development/desa/dspd/world-social-report/2020-2.html (дата обращения: 21.05.2021).

Wild Wide Web. Consequences of Digital Fragmentation [Электронный ресурс] : URL: http://reports.weforum.org/global-risks-report-2020/wild-wide-web/ (дата обращения: 21.05.2021).

\section{References}

Buryanov S. A. Problemy sovershenstvovaniya normativno-pravovoy bazy realizatsii prava na svobodu sovesti v kontekste globalizatsii [Problems of Improvement of the Normative Legal Basis for the Right of Freedom for Conscience in the Context of Globalization] // Gosudarstvo i pravo. 2002. No. 10. Pp. 26-31.

Buryanov S. A. Svoboda sovesti kak global'naya tsennost'. Na puti k politicheskomu edinstvu i resheniyu global'nyh problem [Freedom of Conscience as a Global Value. Toward a Political Unity and a Solution of Global Issues] // Vek globalizatsii. 2009. No. 1. Pp. 136-151.

Buryanov S. A. Nekotorye podhody k opredeleniyu ponyatiya globalizatsii obrazovaniya $\mathrm{v}$ kontekste problemy formirovaniya sistemy upravleniya global'nymi protsessami v interesah ustoychivogo razvitiya [Some Approaches to Defining the Concept of Globalization 
of Education in the Context of the Problem of Global Processes Management for Sustainable Development] // Tsennosti i smysly. 2017. No. 6(52). Pp. 36-49.

Buryanov S. A. O neobhodimosti global'nogo prava v kontekste problemy tselenapravlennogo formirovaniya global'noy sistemy upravleniya $\mathrm{v}$ tselyah ustoychivogo razvitiya [On the Need for Global Law in the Context of the Problem of Purposeful Global Governance for Sustainable Development] // Vek globalizatsii. 2019. No. 4. Pp. 129-142. DOI: 10.30884/vglob/2019.04.12.

Buryanov M. S. Global'nye tsifrovye prava cheloveka v kontekste riskov tsifrovizatsii [Global Digital Human Rights in the Context of Digitalization Risks] // Vek globalizatsii. 2020. No. 3. Pp. 21-37. DOI: 10.30884/vglob/2020.03.05.

Buryanov M. S., Buryanov S. A. Novye ugrozy global'noj bezopasnosti i perspektivy razvitiya mezhdunarodnogo prava [New Threats to the Global Security and the Prospects for the Development of International Law] // Evraziyskiy yuridicheskiy zhurnal. 2020. No. 11 (150). Pp. 35-40.

Buryanov S. A., Kriven'kiy A. I. O sostoyanii i perspektivah formirovaniya global'nogo obrazovaniya, vklyuchaya yuridicheskoe [On the State of and Prospects for Global Education, Including Law Education] // Gosudarstvo i pravo. 2019. No. 8. Pp. 95-100.

Veber A. B. Sovremennyj mir i problema global'nogo upravleniya [The Modern World and the Problem of Global Governance] // Vek globalizatsii. 2009. No. 1. Pp. 3-15.

Grinin L. E. Vozmozhnosti i perspektivy formirovaniya novogo mirovogo poryadka [Opportunities and Prospects for a New World Order] // Vek globalizatsii. 2016. No. 1-2. Pp. 3-18.

Grinin L. E., Grinin A. L. Gryadushhaya tehnologicheskaya revolyutsiya i global'nye riski [The Coming Technological Revolution and Global Risks] // Vek globalizatsii. 2016. No. 4. Pp. 40-58.

Drobot G. A. Problema global'nogo upravlenya v kontekste teorii mezhdunarodnyh otnosheniy [The Problem of Global Governance in the Context of the Theory of International Relations] // Vek globalizatsii. 2011. No. 2. Pp. 41-52.

Il'in I. V., Kaverin M. A. Voprosy preobrazovaniya mezhdunarodnyh organizatsiy v instituty global'nogo upravleniya [The Issues of Transformation of International Organizations into Global Governance Institutions] // Vek globalizatsii. 2014. No. 2. Pp. 32-37.

Il'in I. V., Leonova O. G. Tendentsii razvitiya globalizatsionnyh politicheskih protsessov [Trends in the Development of Globalization Political Processes] // Vek globalizatsii. 2015. No. 1. Pp. 21-35.

Korshunov A. N. Ideja global'nogo prava : filosofsko-metodologicheskie aspekty [The Idea of Global Law : Philosophical and Methodological Aspects] : Ph. D. dissertation. Rostov-on-Don : 2010.

Kochetov E. G. Paradigma Mirovogo Preobrazheniya kak model' budushhego (ee sut' v maksimal'no szhatom vide) [The World Transformation Paradigm as a Model of the Future (its Essence in the Most Concise Form)] // Vek globalizatsii. 2017. No. 3 (23). Pp. 51-60.

Kochetov E. G. Kontur budushhego Rossii: strategija "Geojekonomicheskij hod" [The Contour of Russia's Future: “The Geo-Economic Move Strategy"] // Vek globalizatsii. 2019. No. 2 (30). Pp. 136-148.

Kurcheev V. S., Bolotnikova O. V., Gerasimov J. E. Teoreticheskie osnovy sistematizatsii prava v usloviyah globalizatsii [The Theoretical Foundations of the Systematization of 
Law in the Context of Globalization]. Novosibirsk : Novosibirskij gosudarstvennyj agrarnyj universitet, 2008.

Lepesh G. V. Sovershenstvovanie form vzaimodeystviya mezhdu predpriyatiyami v kontekste tsifrovoy transformatsii [Improving Forms of Interaction Between Enterprises in the Context of Digital Transformation] // Tehniko-tehnologicheskie problemy servisa. 2020. No. 2(52). Pp. 3-10.

Liferov A. P. Osnovnye tendentsii integratsionnyh protsessov v mirovom obrazovanii [The Main Trends of Integration Processes in the World Education] : Doctor of Science dissertation. Ryazan, 1997.

Marchenko M. N. Gosudarstvo i pravo v usloviyah globalizatsii [Government and Law in the Context of Globalisation]. Moscow : Prospekt, 2009.

Romashkina N. P., Markov A. S., Stefanovich D. V. Mezhdunarodnaja bezopasnost', strategicheskaja stabil'nost' i informacionnye tehnologii [International Security, Strategic Stability and Information Technologies]. Moscow : IMEMO RANS, 2020.

Ursul A. D. Globalizatsiya prava i global'noe pravo : konceptual'no-metodologicheskie problemy [Globalization of Law and Global Law : Conceptual and Methodological Problems] // Pravo i politika. 2012. No. 8. Pp. 1284-1297.

Ursul A. D. Global'noe upravlenie : evolyutsionnye perspektivy [Global Governance: Evolutionary Perspectives] // Vek globalizatsii. 2014. No. 1. Pp. 16-28.

Ursul A. D. Stanovlenie obrazovaniya global'nogo mira [Determination of the Global World Education] // Vek globalizatsii. 2019. No. 2. Pp. 49-60.

Farhutdinov I. Z. Mezhdunarodnoe ili global'noe pravo [International or Global Law] // Yurist-mezhdunarodnik. 2004. No. 4. Pp. 15-23.

Chumakov A. N. Global'nyj mir : problema upravlenija [Global World : A Problem of Governance] // Vek globalizatsii. 2010. No. 1. Pp. 3-15.

Chumakov A. N. Kul'tura i vyzovy globalizacii : novye podhody [Culture and the Challenges of Globalization : New Approaches] // Vek globalizatsii. 2011. No. 2(8). Pp. 174-180.

Chumakov A. N. Problema upravleniya kak povod dlya diskussii [Governance Issues as a Discussion Point] // Vek globalizatsii. 2012. No. 2. Pp. 35-42.

Chumakov A. N. Osnovnye trendy mirovogo razvitiya : realii i perspektivy [Basic Trends in World Development: Realities and Prospects] // Vek globalizatsii. 2018. No. 4(28). Pp. 3-15. DOI: https://doi.org/10.30884/vglob/2018.04.01.

Chumakov A. N. Global'nyj mir : stolknovenie interesov [Global World : A Conflict of Interests]: monography. Moscow, 2019.

Shumilov V. M. Kontseptsiya Global'noy pravovoy sistemy [The Concept of the Global Law System] // Yurist-mezhdunarodnik. 2003. No. 3. Pp. 46-52.

Bostrom N. Superintelligence. Paths, Dangers, Strategies. Oxford : Oxford University Press, 2014.

Buryanov M. Here's Why We Need a Declaration of Global Digital Human Rights // World Economic Forum. 2020. URL: https://www.weforum.org/agenda/2020/08/here-swhy-we-need-a-declaration-of-global-digital-human-rights/ (accessed: 21.05.2021).

Buryanov S. A. State Worldview Neutrality in the Context of Deteriorating Imbalances in Globalization. Amsterdam : International Humanist and Ethical Union, 2018. 
Farkhutdinov I. The Mysterious and Obvious in American Diplomacy: From Monroe to Trump. Newcastle upon Tyne : Cambridge Scholars Publishing, 2020.

Futter A. Hacking the Bomb: Cyber Threats and Nuclear Weapons. Georgetown : Georgetown University Press, 2018.

Harris S. War : The Rise of the Military-Internet Complex. Boston : Houghton Mifflin Harcourt, 2014.

Rosenau J. N., Czempiel E.-O. Governance Without Government : Order and Change in World Politics. Cambridge : Cambridge University Press, 1992.

Schwab K. Shaping the Fourth Industrial Revolution. Cologny / Geneva : Portfolio Penguin, 2018.

Slaughter A. M. A New World Order. Princeton and Oxford : Princeton University Press, 2004.

UNDESA World Social Report 2020. URL: https://www.un.org/development/desa/ dspd/world-social-report/2020-2.html (accessed: 21.05.2021).

Wild Wide Web. Consequences of Digital Fragmentation. URL: http://reports.weforum. org/global-risks-report-2020/wild-wide-web/ (accessed: 21.05.2021). 